\title{
Jerusalén entre las señas de la identidad y el avivamiento de la resistencia en la poesía de Mahmoud Darwis
}

\author{
Jerusalem between the Inscription of Identity and Enhancement of \\ Resistance in Mahmoud Darwish's Poetry
}

القــدس بين نقوش الهوية واشتعال المقاومة في شعر محمود درويش

Recibido: enero 2010

DR. Ibrahim N. MOUSA

Birzeit University

Imusa@birzeit.edu

Aceptado: octubre 2010

RESUMEN:

Este trabajo de investigación estudia la imagen de Jerusalén [Al-quds] desde una perspectiva estilística, a través de dos ejes. El primero se concentra en el fenómeno de la "historia y la identidad," que no sólo hunde profundamente sus raíces en el significado de que el palestino es el dueño de la historia y la geografía, formando su identidad nacional y su ser cultural, pero también como una respuesta al enemigo que confisca la identidad del lugar de Palestina. El segundo eje revela la tragedia de la vida Palestina, representada en la crudeza de la ocupación, en destruir y matar, como intento de desplazar todo el pueblo por la fuerza, o exiliarle fuera del lugar y el tiempo. Pero todo esto nunca evitará que el Palestino deje de agarrarse a su derecho a vivir, defendiendo su tierra, su nación y su Jerusalén; y así la defensa de todo ello es una defensa de su memoria y de su existencia humana.

Palabras clave: Poesía de Mahmud Darwish. Jerusalén. Identidad. Ocupación. Resistencia. Desastre.

\section{ABSTRACT}

This study sheds lights on the image of Jerusalem in Mahmoud Darwish's Poetry from a stylistic perspective in two sections: the first concentrates on " history and identity" phenomenon which has its deep roots in the Palestinian history and geography. This formed the National identity and the cultural being for the Palestinian as a response to the enemy's attempts to confiscate the identity of the Palestinian Place.

The second section reveals "occupation and resistence" the tragic Palestinian life represented in the occupation's cruelty and displacement of a whole nation. However, this will not prevent the Palestinian from clinging to his right in defending his land and his Jerusalem since defending them is an obvious manifestation guarding of his memory and human existence.

Key words: Mahmud Darwish's Poetry. Jerusalem. Identity. Occupation. Resistance. Disaster.

$$
\begin{aligned}
& \text { يتناول هذا البحث دراسة صورة القدس في شعر محمود درويش در اسة أسلوبية، من خلال محورين اثثين: ارتكز الأول على استجلاء }
\end{aligned}
$$

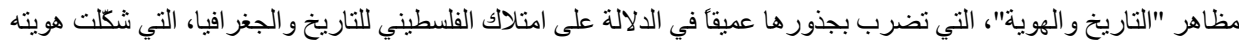

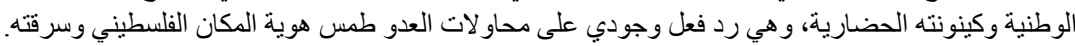

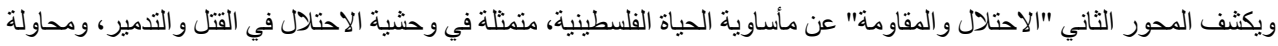

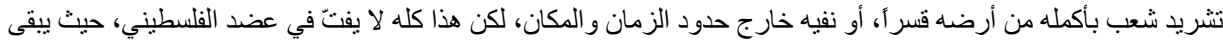

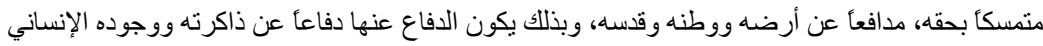

$$
\begin{aligned}
& \text { كلمات مفاتيع: شعر محمود درويش القس. الهويّهة. الاحتلال. المقاومة. النكبة. }
\end{aligned}
$$




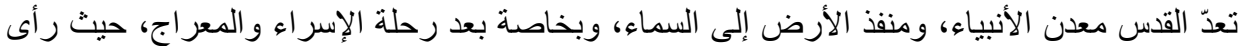

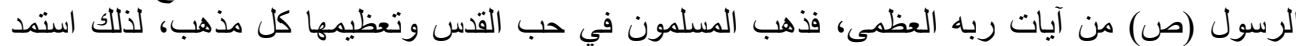

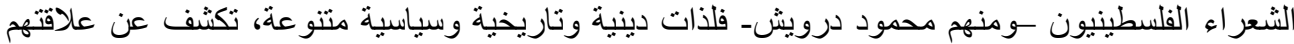

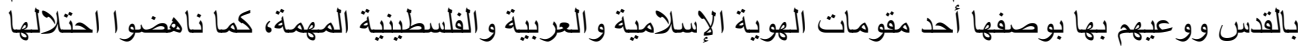
وتهجير أهلها منها.

تأسست القدس منذ ما يقارب الخمسة آلاف عام على يد الييوسيين العرب ـو هم فرع من الكنعانيين-

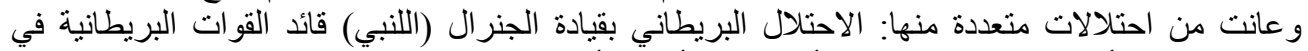

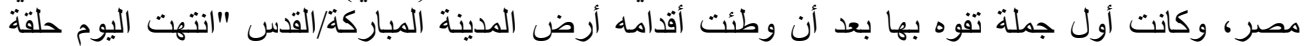

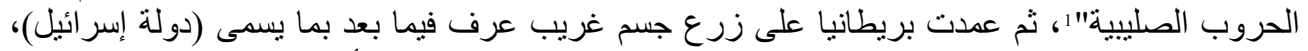

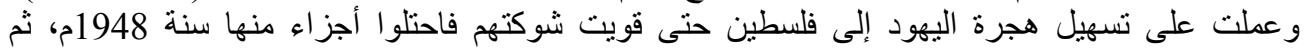

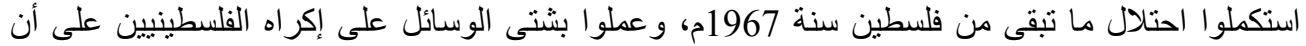

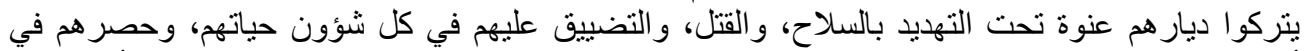

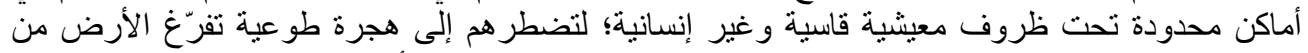

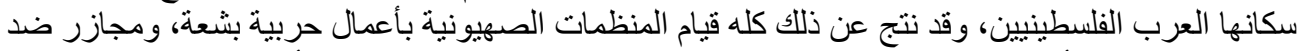

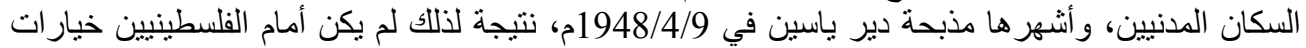

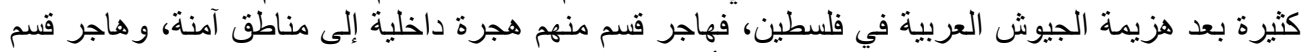

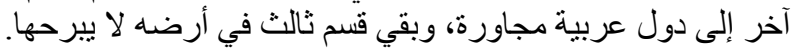

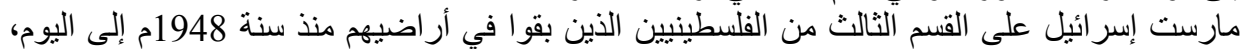

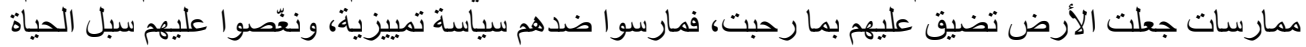

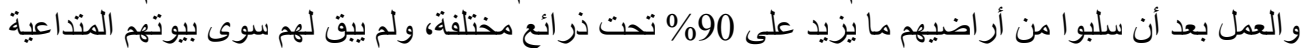

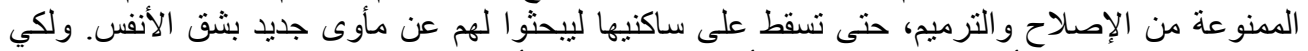

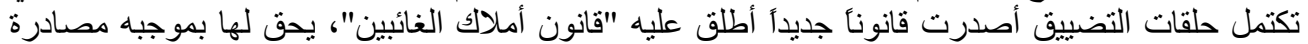

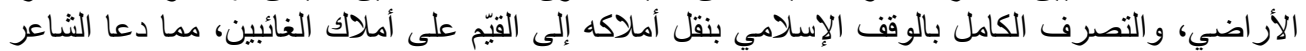
الفلسطيني راثد حسين في إحدى قصائده إلى أن يصر خ قائلا:

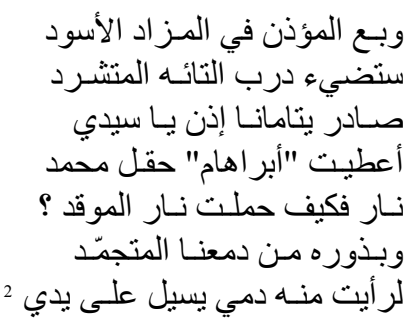

$$
\begin{aligned}
& \text { وبع الكنبسة فهي من أملاكه } \\
& \text { و اطفئ ذبالات النجوم فإنها } \\
& \text { حتى يتامانسا أبو هـ "غـائب الجرت } \\
& \text { حررت حتى السائمات غداة أن أن أن }
\end{aligned}
$$

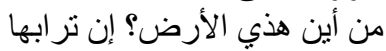

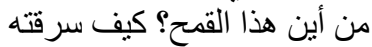

$$
\begin{aligned}
& \text { أنا لو عصرت رغيف خبزك في يدي }
\end{aligned}
$$

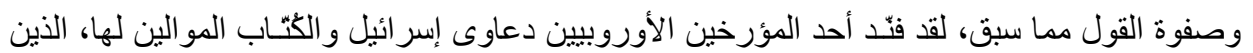

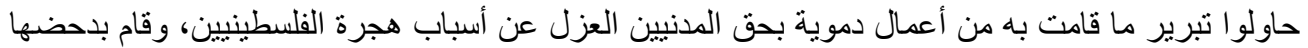

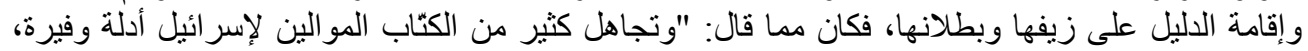

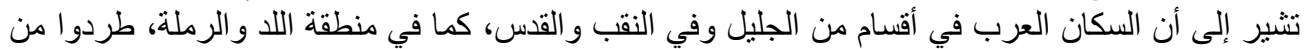


بيوتهم عنوة وبعنف مفرط خلال المر احل الأخيرة للحرب...وفي بعض البلدان والمدن بُذلت جهود لإخلاء

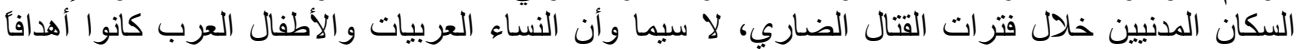

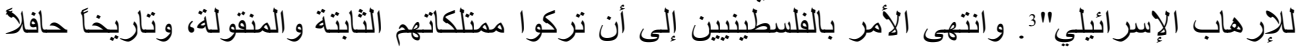

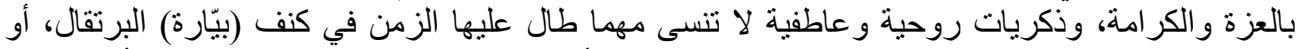

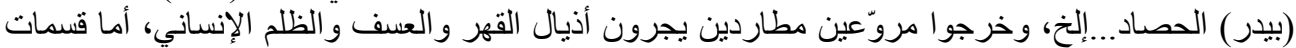
وجو ههم فتقول المأساة وتصلنا بأبعادها. وخدا. بناء على ما سبق، استحضر محمود درويش مدينة القدس لتجسيد صورة من صور الهور الهوية ومقاومة

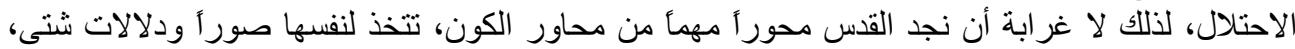

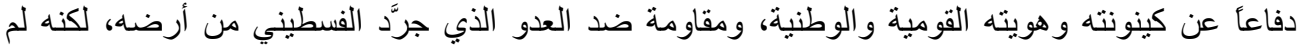

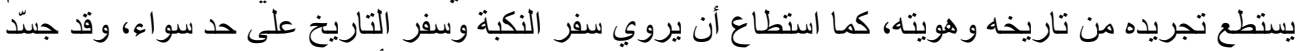

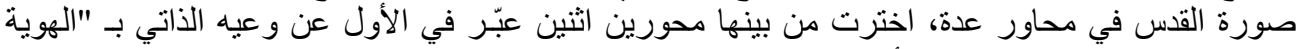

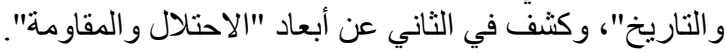

\section{1 القدس/الهويـة والتاريخ}

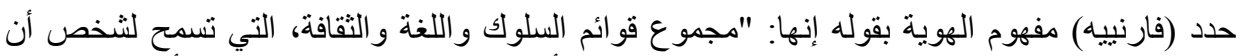

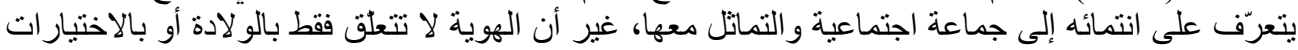

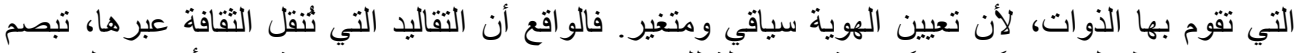

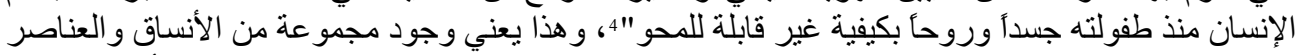

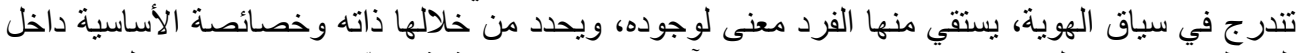

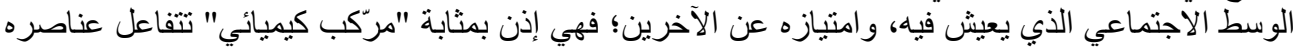

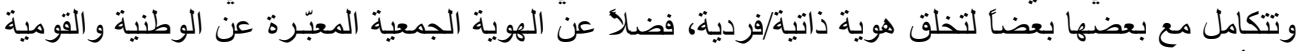

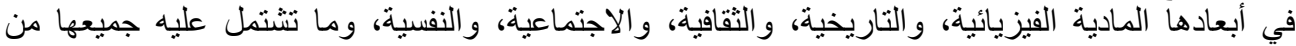

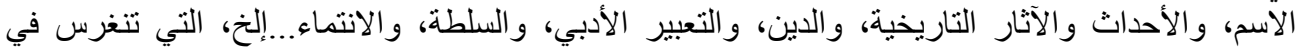
الذاكرتين الفردية و الجماعية. شكلت هذه الحصبلة العلائقية للهوية هاجسأ شعرياً، ومظهر آ شخصياً ووطنياً وقومياً في شعر محمود

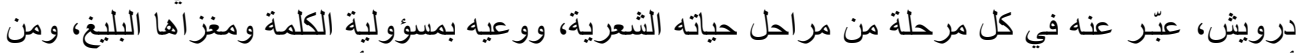

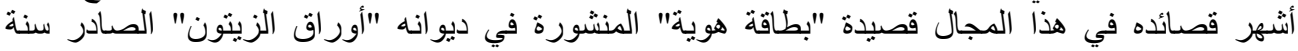

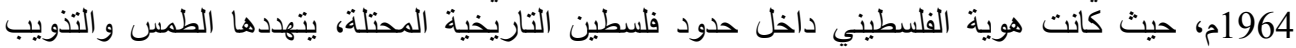

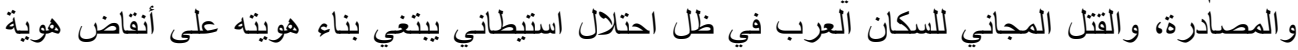

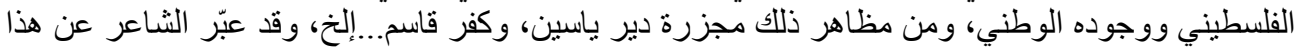
كله في دواوينه الثعرية ومنها ديو انه "حالة حصار "، الذي أكد فيه خطأ هذه السياسة، وخطيئة ممارساتها

الدموية بقوله: دوانه

$$
\begin{aligned}
& \text { (إلى قاتل): لو تأملت وجه الضحية }
\end{aligned}
$$

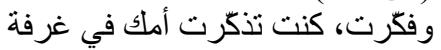

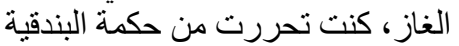

$$
\begin{aligned}
& \text { و غيّرت رأيك: ما هكذا تستعاد الهوية } 5
\end{aligned}
$$

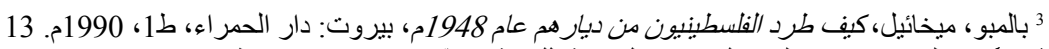

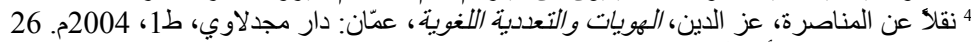

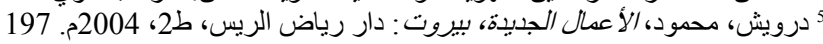


بقي هاجس الهوية ير اود الثاعر، ويتأجج حضوره لإدر اكه بتغاير هويته عن هوية الآخر اليهودي، الذي وني

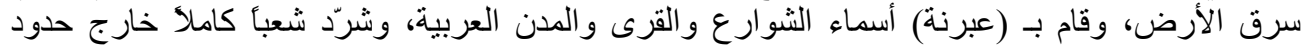

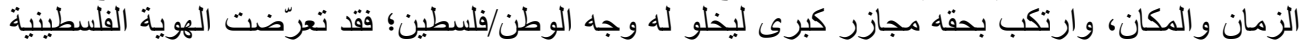

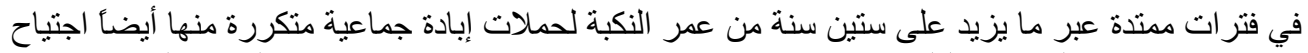

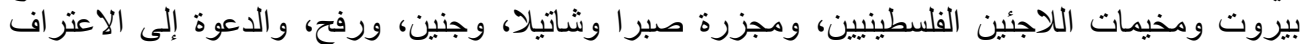

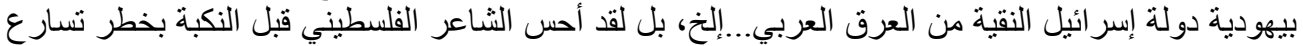

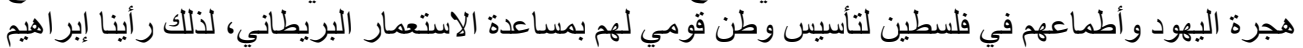
طوقان (1905م-1941م) يعلن عن هويته الفلسطينية المتعلقة بالمهنة (الفلاحة)، مقابل هوية الآخر الئنية اليهودي

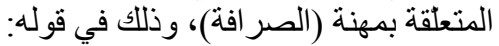

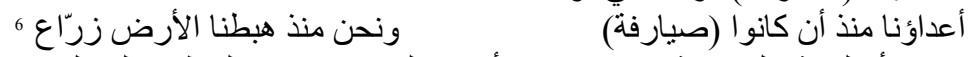

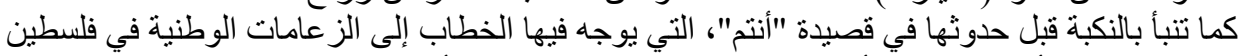

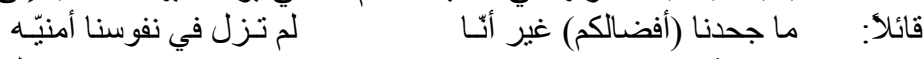

في يدينـا بقية مـن بـلاد

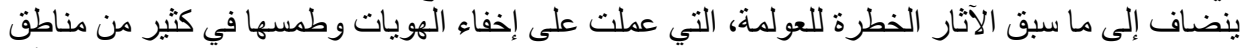

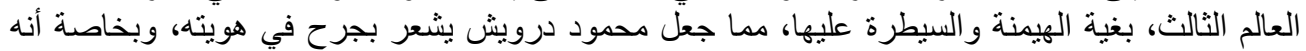

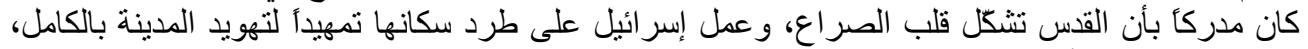
كما كان مدركأ لما أصاب هوية فلسطين/القدس من تمزيق وجر احن، وفي وفي هذا المعنى يقول:

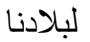

$$
\begin{aligned}
& \text { وهي القريبة من كلام الله } \\
& \text { سقف من سحاب القزب كن كن } \\
& \text { لبلادنا } \\
& \text { وهي البعيدة عن صفات الاسم } \\
& \text { خارطة الغياب } \\
& \text { لبلادنا } \\
& \text { و وهي الصغيرة مثل حبة سمسم } \\
& \text { أفق سماوي...و هاوية خفية } \\
& \text { لبلادنا } \\
& \text { كتب سماوية...ووجر ح في الهوية الهنة }
\end{aligned}
$$

إذا كانت العو امل السابقة ومنها العولمة تمس بهوية لهوية الفلسطيني، فإن العولمة من وجهة أخرى "أيقظت

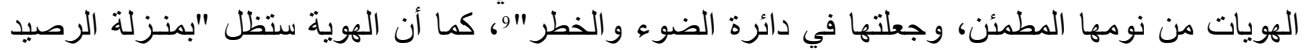

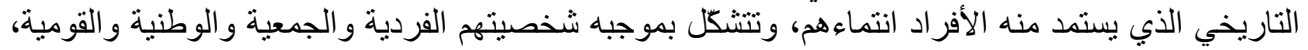

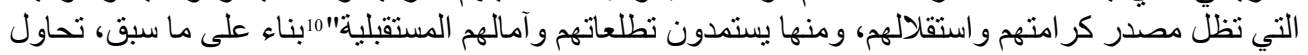

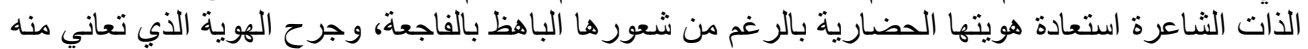

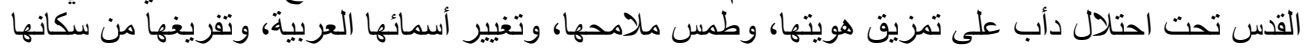

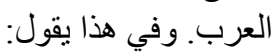
هنا القدس

$$
\begin{aligned}
& 6 \text { طوقان، إبر اهيم، دبوان إبراهيم، بيروت: دار الثرق الجديد، د.ت. } 51 \\
& 7 \text { ما سبق، (صنان، }
\end{aligned}
$$

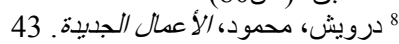

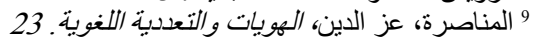

$$
\begin{aligned}
& 10 \text { ما سبق، } 35
\end{aligned}
$$




$$
\begin{aligned}
& \text { يا امر أة من حليب البلابل، كيف أعانق ظلي } \\
& \text { و أبقى ؟ أمن } \\
& \text { خلقت هنا. وتنام هناك }
\end{aligned}
$$

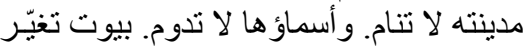

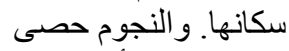

$$
\begin{aligned}
& \text { وخمس نو افذ أخرى، و وعثر نو افذ أخرى تغادر } \\
& \text { حائط } \\
& \text { وتسكن ذاكرة...و السفينة تمضي }
\end{aligned}
$$

تنم إثار ات الثاعر اللغوية والدلالية في سياق الأبيات عن تلميح أبلغ من التصريح في تصوير فاجعة

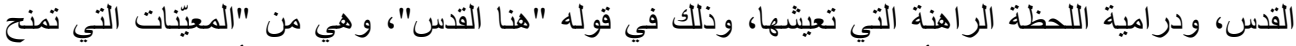

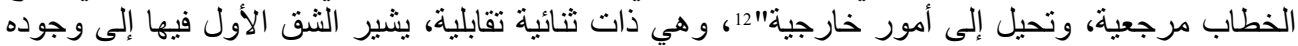

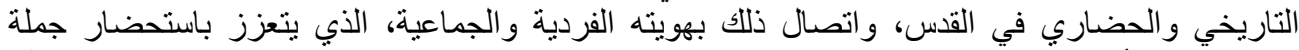
"خلقت هنا". أما الثق الثاني فذو دلالة صريحة تفتقد فيها الذات الثاعرة مدينة القدس التي لا تملكها الآن

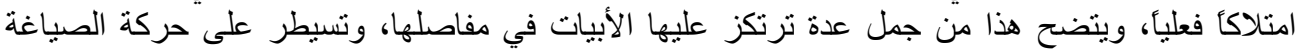

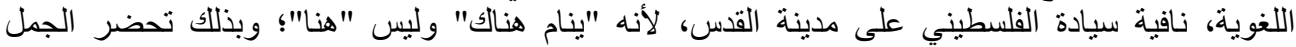

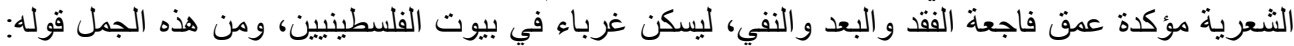

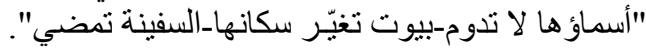
ثم يصحو الثاعر في قصيدة "أرى ما أريد" على فاجعة حضارئل حضارية أخرى، حين يجد التاريخ الكنعاني،

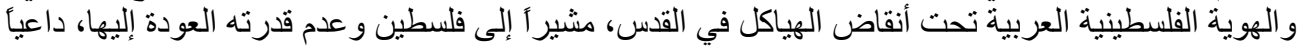

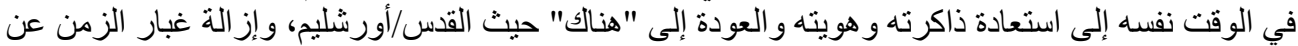

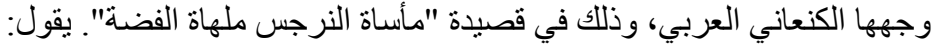

$$
\begin{aligned}
& \text { خذني إليّ لأنتمي لجنازتي في يوم عيدي } \\
& \text { خذني إلى عيدي شهيداً في بنفسجة الثي الثهيد }
\end{aligned}
$$

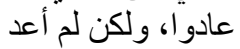

$$
\begin{aligned}
& \text { خذني هناك إلى هناك من الوريد إلى الوريد }
\end{aligned}
$$

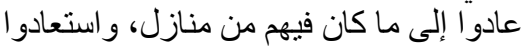

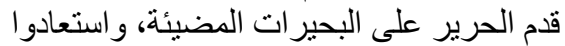

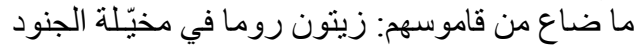

$$
\begin{aligned}
& \text { تور اة كنعان الدفينة تحت أنقاض الهياكل بين صور و وأورشئيم } 13
\end{aligned}
$$

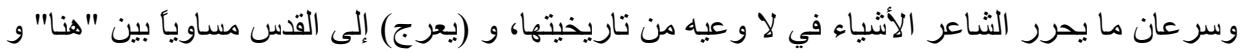

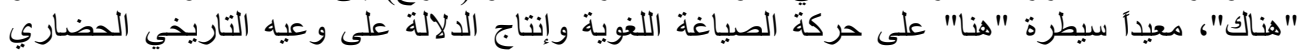

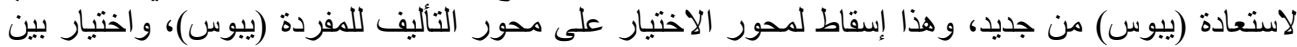

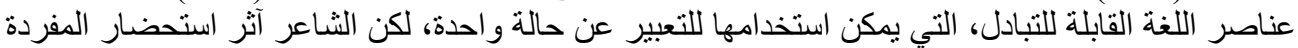

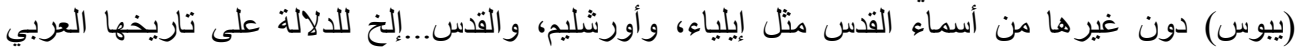
الضارب في أعماق التاريخ، حيث كان اليبوسيون ــوهم فرع من الكنعانيين العربـ أول من منحها هذا الاسم

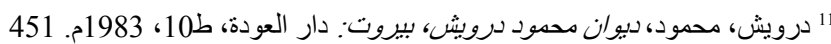

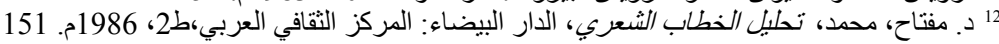

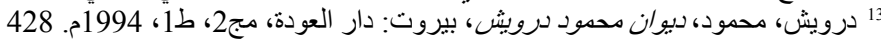


بعد نأسيسهم لها قبل ما يقارب الخمسة آلاف عام، و هذا لا يخلو من محاولة استعلاء على الو اقع المعيش، أو تعويض نفسي عن امتلاك المكان. وذلك في قصيدة "بغيابها كوّتت صورنها" الافي من يقول:

$$
\begin{aligned}
& \text { وكأنني شبح تسلل من يبوس، وقلت لي: }
\end{aligned}
$$

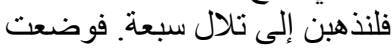

$$
\begin{aligned}
& \text { أقنعتي على حجر ، وسرت كمئ كما يسير } \\
& \text { النائمون يقودني حلمي. ومن قمر إلى كئى } \\
& \text { قمر ققزت. هنالك ما يكفي من اللاو عي تئي }
\end{aligned}
$$

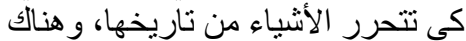

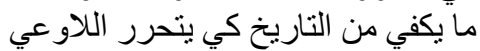

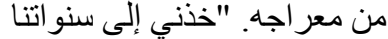

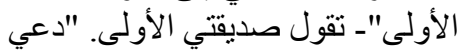

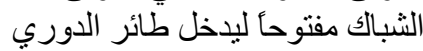

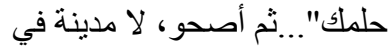

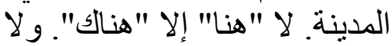

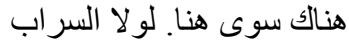

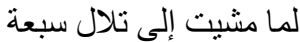

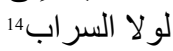

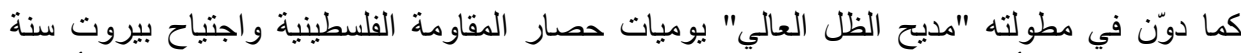

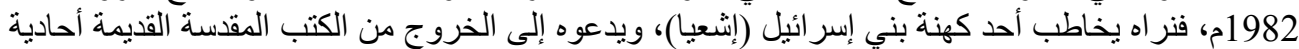

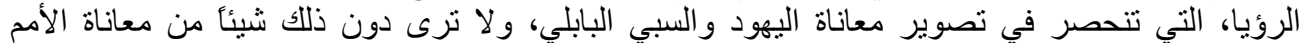

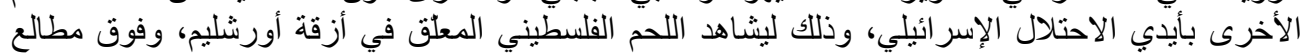

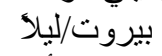

لا ظلام أثند من هذا الظلام

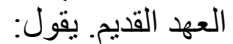

$$
\begin{aligned}
& \text { يضيئني قتلي } \\
& \text { أمن حجر يقدّون النعاس؟ } \\
& \text { أمن مز امير يصكون السلاح؟ } \\
& \text { ضحية أمن فير } \\
& \text { قتلت } \\
& \text { ضحيتها } \\
& \text { وكانت لي ضحيتها } \\
& \text { وكانت لي هويتها }
\end{aligned}
$$

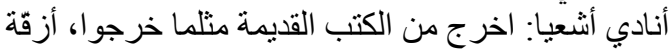
أورشليم تعلق اللحم الفلسطيني فوق مطالع العهد القديم القيم

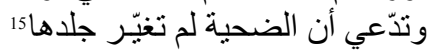

تنهض الأبيات على محورين دلاليين: الأول توظيف أسلوب اليوميات، والثاني استحضار شخصية

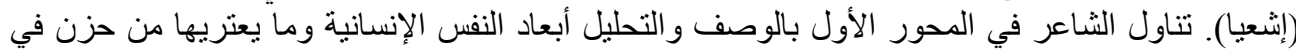

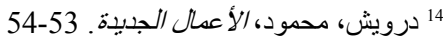

$$
\begin{aligned}
& 15 \text { درويش، محمود، ديوان محمود درويش، مج2. 40-41-4 }
\end{aligned}
$$


لحظات زمنية متتابعة أو متقطعة، وهو عندما يفعل ذلك يلقي بتصوره فيما يدور حوله من أحداث، ويفصح

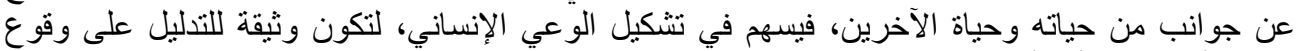

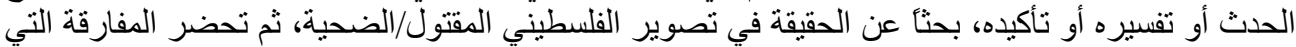

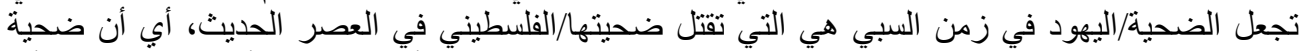

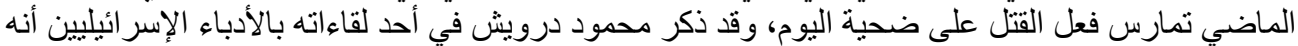

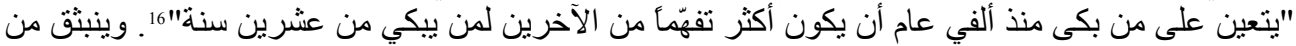

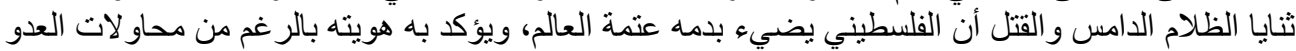

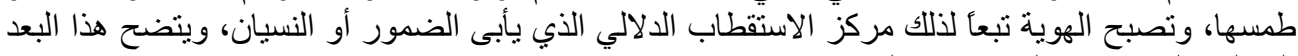

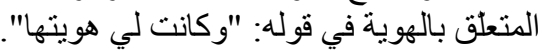

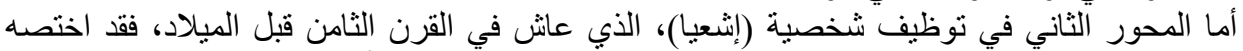

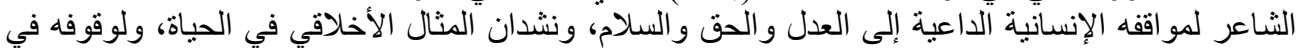

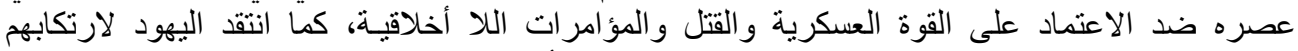

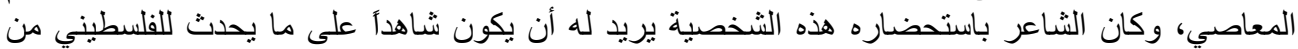

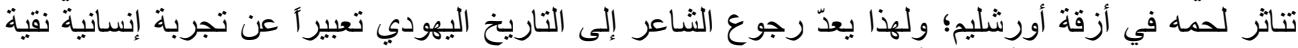

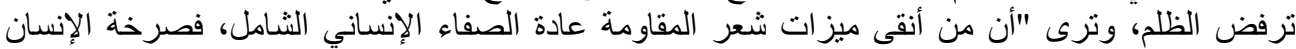

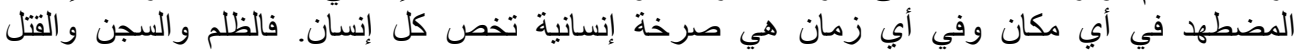

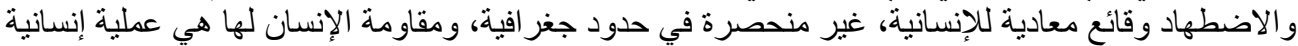

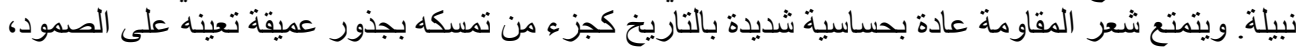

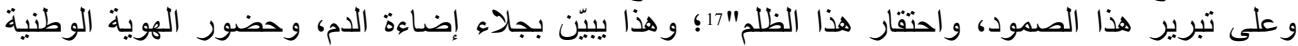
و القومية و الإنسانية.

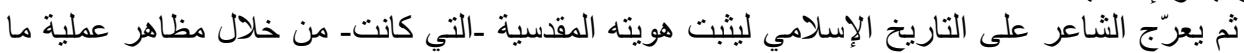

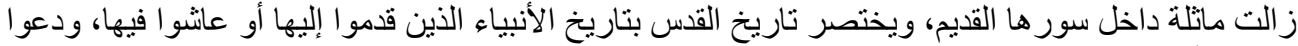

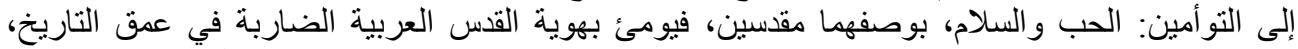

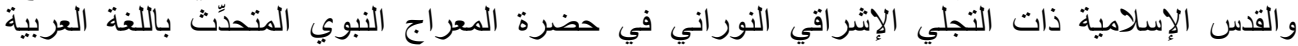

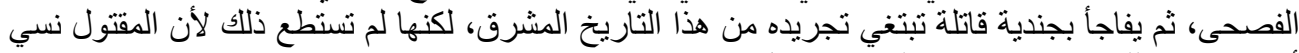

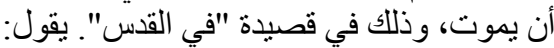

$$
\begin{aligned}
& \text { في القدس، أعني داخل السور القديم }
\end{aligned}
$$

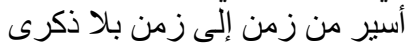

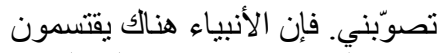

$$
\begin{aligned}
& \text { تاريخ المقدّس...يصعدون إلى إنى السماء } \\
& \text { ويرجعون أقل إحباطأ وحزنأ، فالمحبة المباء } \\
& \text { و السلام مقدّسان وقادمان إنان إلى المدينة } \\
& \text { كنت أمشي فوق منحدر و أهمس: كيف إلى المدان }
\end{aligned}
$$

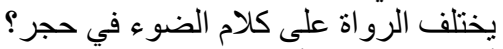

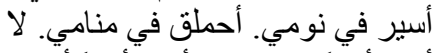

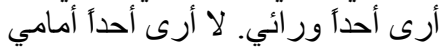

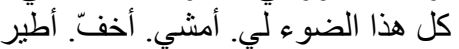

$$
\begin{aligned}
& \text { أنا لا أنا في حضرة الضوة لئري. }
\end{aligned}
$$




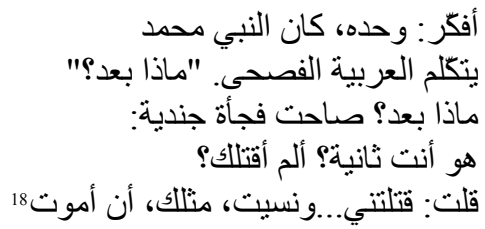

يتبدى في الأبيات ثلاث إثار ات دلالية ذات أهمية في تجسيد رؤية الثاعر التاريخية، و استحضار أبعاد

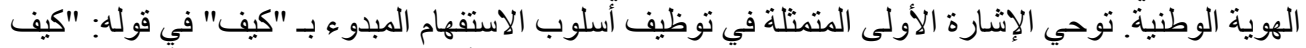

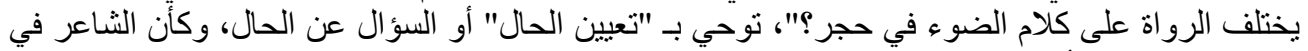

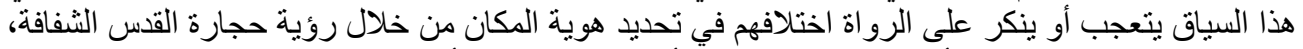

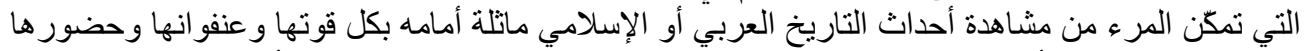

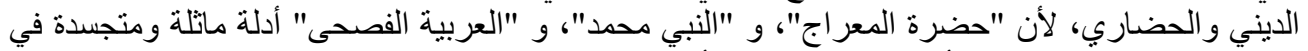

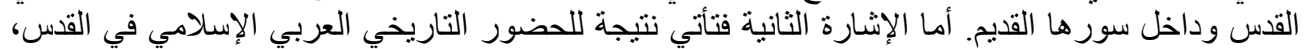

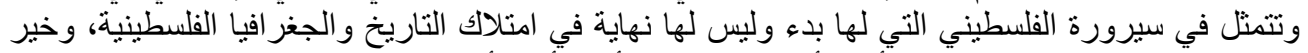

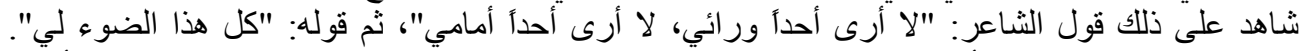

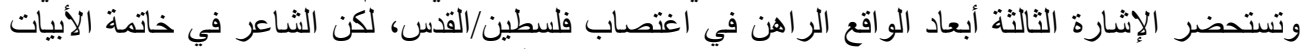

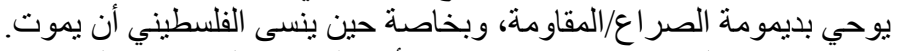

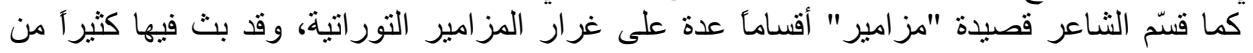

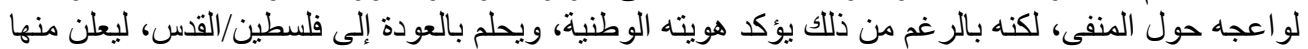
عن وجوده. يقول في المزمور/القسم الثاني عثر من القئ القصيدة:

$$
\begin{aligned}
& \text { طوبى لمن يعرف حدود سعادتي } \\
& \text { طوبى للرب الذي يقر أ حريتي }
\end{aligned}
$$

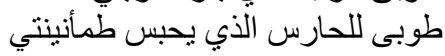

$$
\begin{aligned}
& \text { في عينيه الساهرتين } \\
& \text { طوبى لمن بفهم ما معنى أن أكون النين } \\
& \text { السجين و السجّان في آن واحد } \\
& \text { أيتها النو افذ البعيدة كالحب الأن والأول }
\end{aligned}
$$

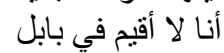

$$
\begin{aligned}
& \text { بابل هي التي تسكن في تقاطيع وجهي } \\
& \text { أينما ذهبت } \\
& \text { ويا أيتها النو افذ البعيدة كالحب الأول } \\
& \text { أنا لست منفياً النيا } \\
& \text { في قلبي نفيت المنفى، وذهبت } \\
& \text { المطر يتساقط في الخارج } \\
& \text { بلا سبب } \\
& \text { والقحط ينتشر في الداخل لأسباب كثيرة } \\
& \text { فمن يعيد ترتيب الفصول إنيان } \\
& \text { ومن بعلمني مر اثي إرميا } \\
& \text { في طرق أورشيليم التي لعنها الرمبا لرب }
\end{aligned}
$$

18 درويش، محمود، الأعدال الجديدة. 52-51 


$$
\begin{aligned}
& \text { لكي أعلن للمرة الأولى } \\
& \text { تاريخ ميلادي للمي } \\
& \text { مَنْ بَ } 19
\end{aligned}
$$

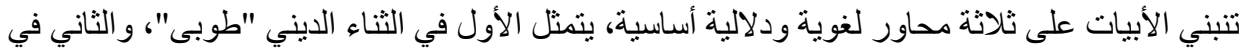

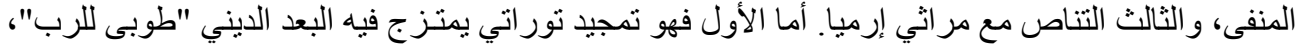

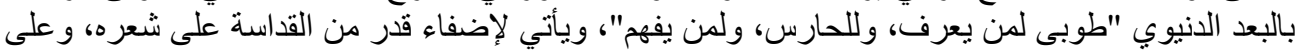

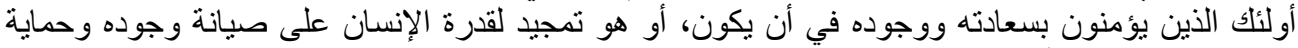

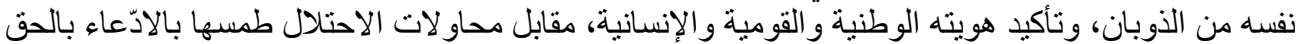

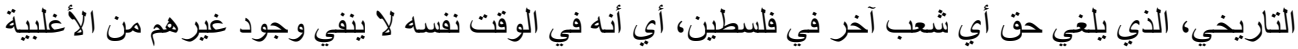

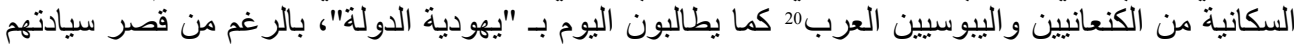

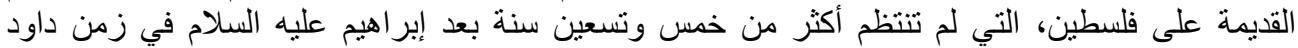

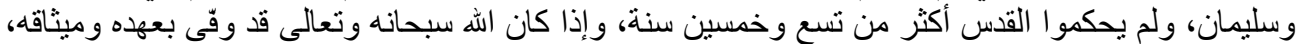

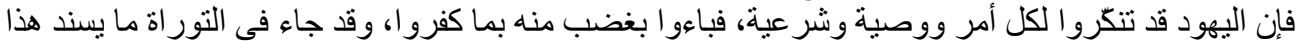

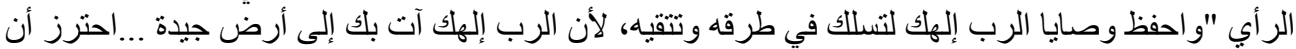

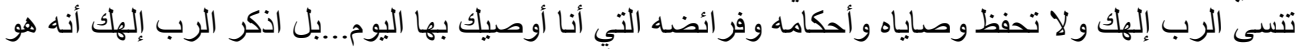

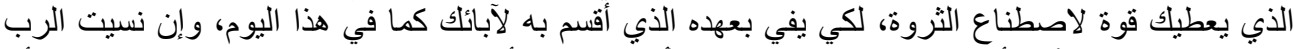

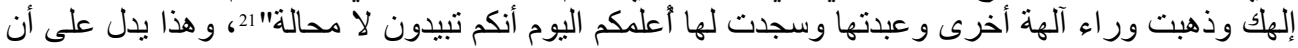

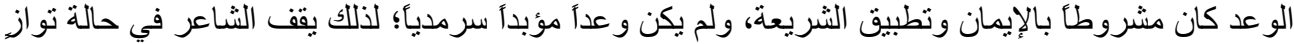

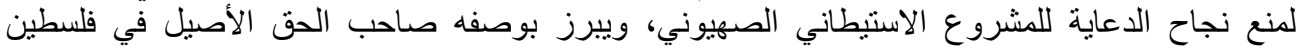

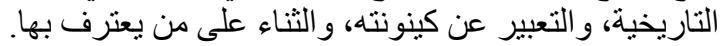

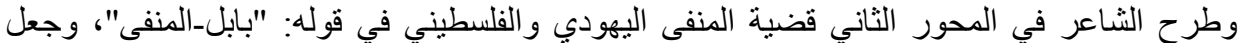

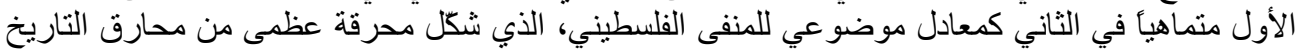

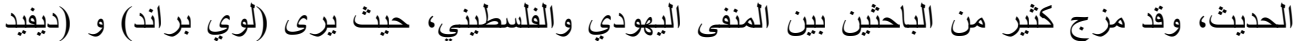

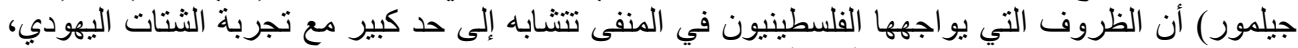

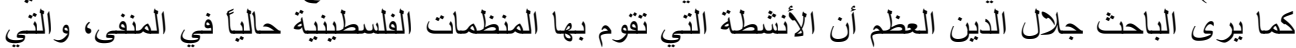

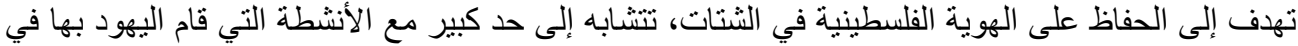

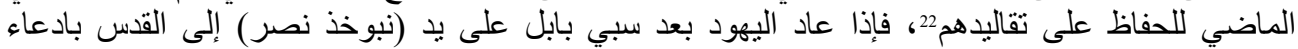

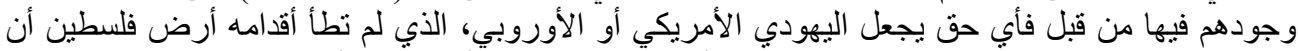

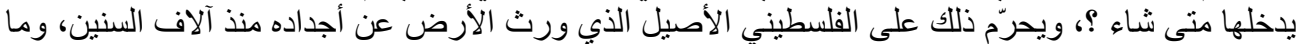

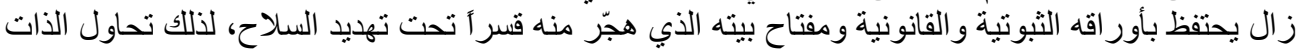

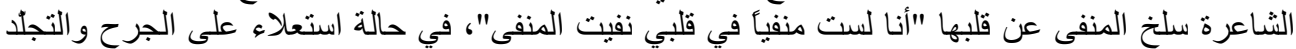

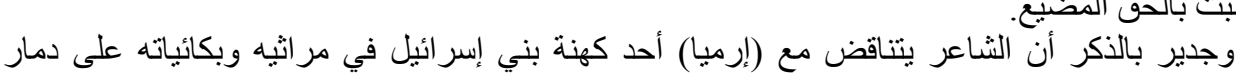

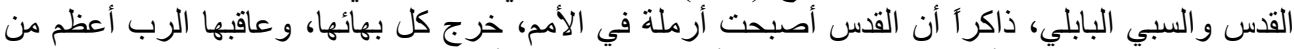

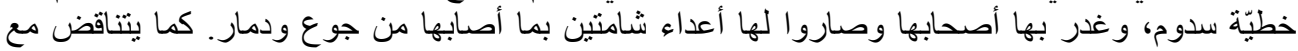

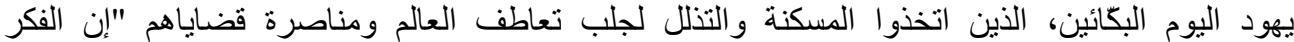
الصهيوني بطرحه هذا المطلب، يدرك تمامأ مدى حساسية هذه المسألة. فللمرة الأولى تفتح صفحة إيجابية في

$$
\begin{aligned}
& 19 \text { درويش، محمود، ديو ان محمود درويش. 389-390 } \\
& 20 \text { انظر العهد القديم، سفر الثنية، الإصحاح } 7 \text { دان }
\end{aligned}
$$

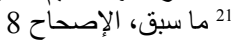

22 نقلا عن د. الرفاعي، جمال أحمد، ثث الثقافة العبرية في الشعر الفلسطيني الدعاصر ، مصر: دار الثقافة الجديدة، 1994م. 33 
حوليات المراثي والبكائيات الصهيونية، مع عدم التخلي بالطبع عن النواح والثكوى، اللذين يقدمان وسيلة

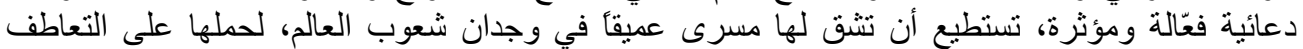

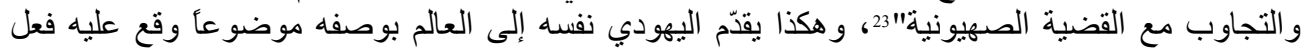

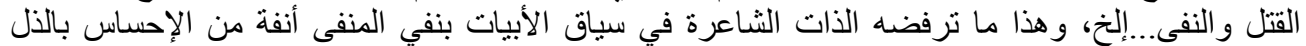

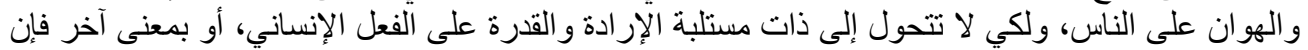
البكاء لا يعيد أوطانأ سلبت. ولني. أما المحور الثالث فيتناص فيه الثاعر بشكل مباثشر مع مر اثي (إرميا) في أبعادها العامة، ويطلب أن أن أناء

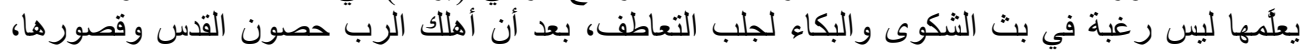

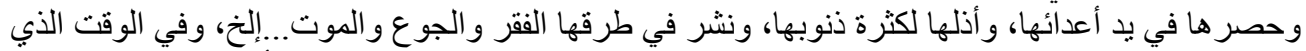

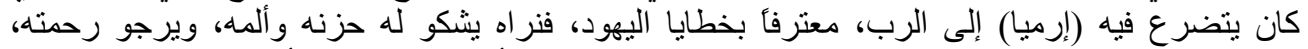

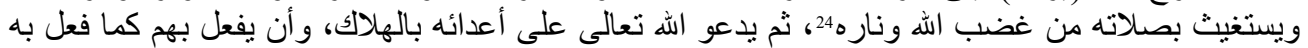

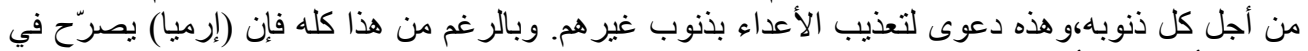

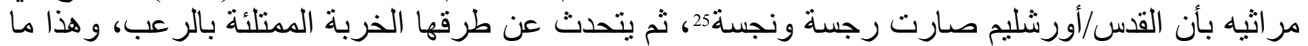

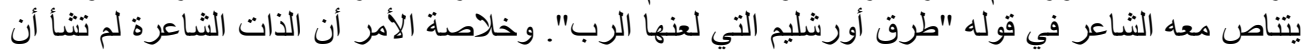

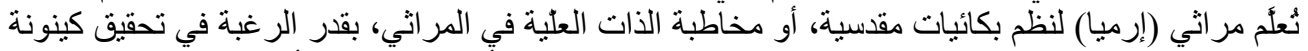

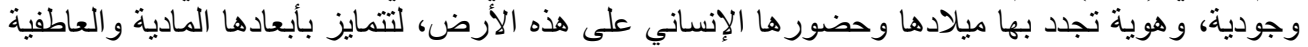

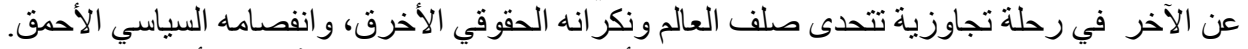

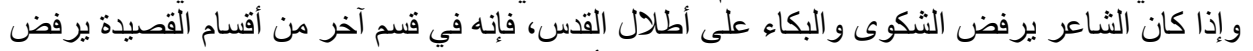

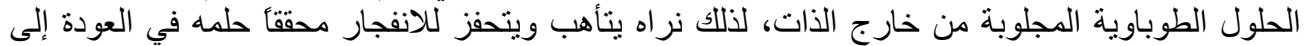

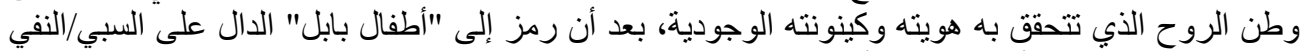

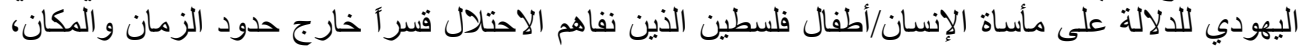

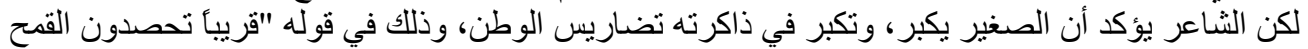

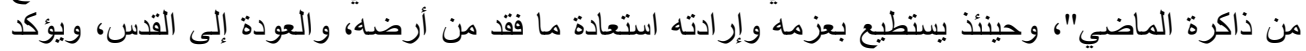

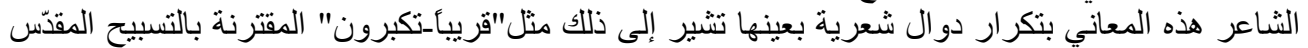

$$
\begin{aligned}
& \text { إني أتأهب للانفجار } \\
& \text { على حافة الحلم } \\
& \text { كما تتأهب الآبار اليابسة } \\
& \text { للفيضنان } \\
& \text { ونغني القدس } \\
& \text { يا أطفال بابل القذيل }
\end{aligned}
$$

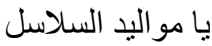

$$
\begin{aligned}
& \text { ستعودون إلى القدس قريبا } \\
& \text { وقريباً تكبرون } \\
& \text { وقريباً تحصدون القمح من ذاكرة الماضي } \\
& \text { قريباً يصبح الدمع سنابل ندابل }
\end{aligned}
$$

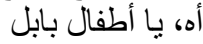

$$
\begin{aligned}
& \text { ستعودون إلى القدس قريبا }
\end{aligned}
$$

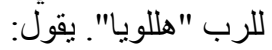

$$
\begin{aligned}
& 23 \text { أمين، بديعة، الأسس الأبيديولوجية للأدب الصعيوني، بغداد: دار الثؤون الثقافية العامة، 1989م. } 314
\end{aligned}
$$

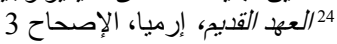

$$
\begin{aligned}
& 125
\end{aligned}
$$




$$
\text { وقريباً تكبرون }
$$

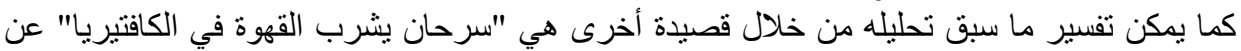

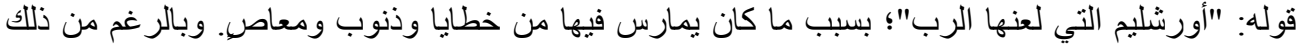

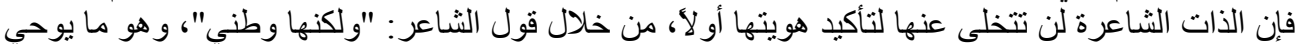

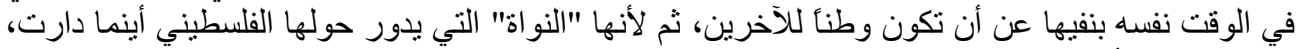
ويتوجب عليه أن يخلصها من اللعنة والنجاسة التي لحقت بها، ويعيد لها بهاءها، وكمال جمالها، ويجعل منها بهجة الأرض، ويهيء لها تربة صالحة تطهر ها، فضلا عن كونها الوطن و التاريخ و الهوية. يقول:

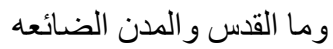
سوى منبر للخطابه ومستود القدن للكآبه وما القدس إلا زجاجة خمر وصندوق تبغ....

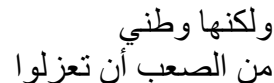
عصير الفو اكه عن كريات دمي تعزي

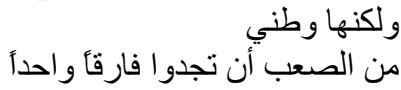
بين حقل الذره وبين تجاعيد كفي

$$
\begin{aligned}
& \text { ولكنها وطني وبني }
\end{aligned}
$$

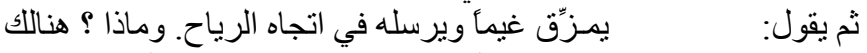

$$
\begin{aligned}
& \text { غيم شديد الخصوبة. لا بد من نربة صدالحها }
\end{aligned}
$$

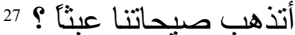

إن تحول القدس والمدن الفلسطينية الأخرى إلى منبر للخطابة العربية البليغة، كما أن تحولها بأيدي

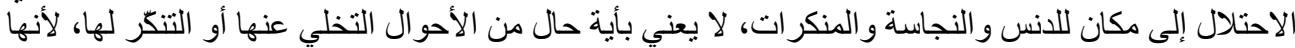

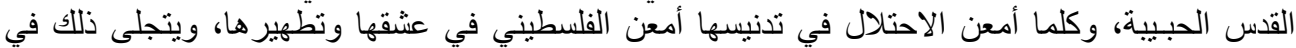

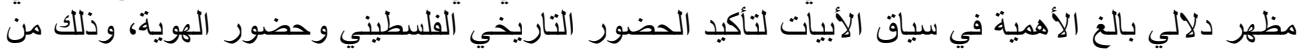
خلال فعل الزراعة "حقل الذرة-تجاعيد كفي"؛ وبالرغم من البساطة الظاهرة لمفهوم الهوية بهذا المعنى، إلإيا

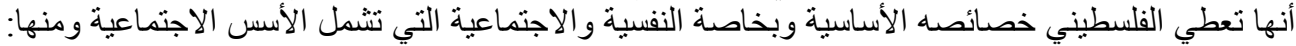

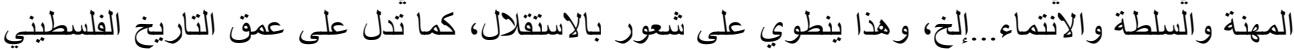
الذي يأخذ فيه وجوده الحضاري، وبخاصة أن "تجاعيد الكف" التي ما زالت حاضرة حتى اليوم، تخترق

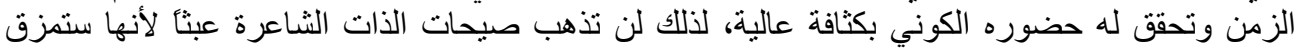
حجب الظلام، وتغيّر وجه القدس المظلم. 


\section{2 القدس/الاحتلال والمقاومـة}

استباحت إسر ائيل لنفسها امتلاك الجغر افيا دون وجه حق بتشريد مئات الآلاف من الفلسطينيين تحت

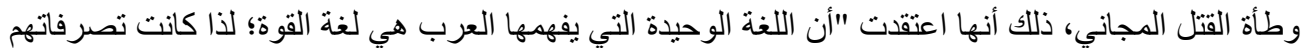

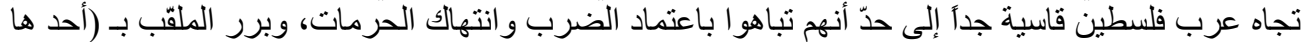

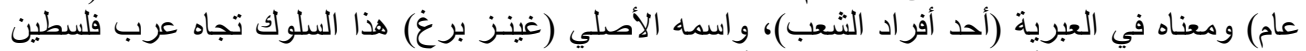

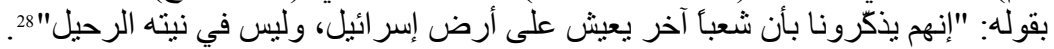

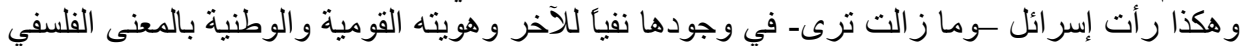

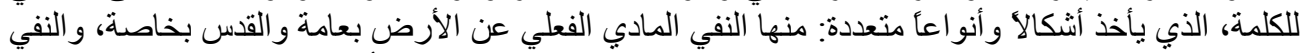

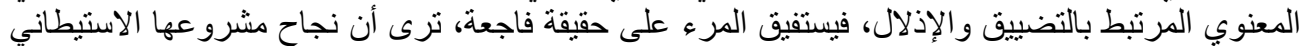

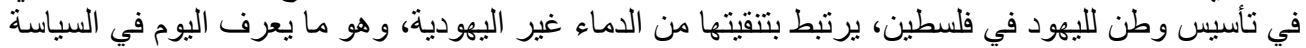

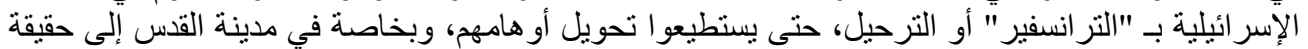
بالأمر الو اقع.

بناء على ما سيق استحضر محمود درويش مشهداً مأساوياً من حياة الشعب الفلسطيني تحت نير الاحتلال

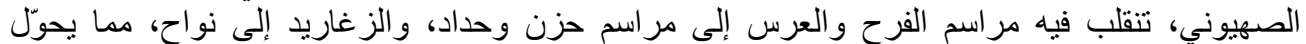

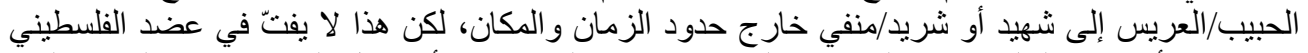

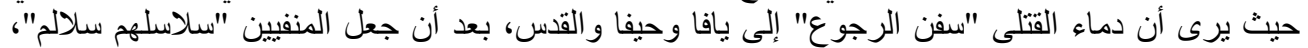

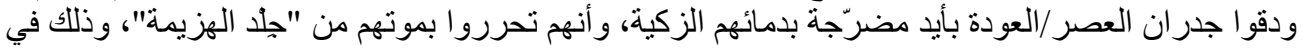

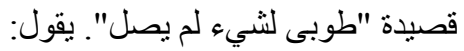

$$
\begin{aligned}
& \text { و على حدود القدس } \\
& \text { أفلست الحو اس، وحاسة الدام أينعت فيهم } \\
& \text { وقادتهم إلى الوجه البعيد } \\
& \text { هربت حبييتهم إلى أسو ارهار البعا وغز اتها } \\
& \text { فتمردو اتوبات } \\
& \text { وتوحّدوا }
\end{aligned}
$$

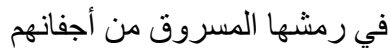

$$
\begin{aligned}
& \text { وتسلقو ا جدران هذا العصر العر إن } \\
& \text { دقو ا حائط المنفى إنى } \\
& \text { أقامو ا من سلاسلهم سلانلم المني } \\
& \text { ليقبّلو أقدامها } \\
& \text { فاكتظ شعب في أصابعهم خو اتم } \\
& \text { هذا هو العرس الذي لا ينتهي } \\
& \text { في ساحة لا تنتهي الأي } \\
& \text { هذا هو العرس الفلسطيني لاهني } \\
& \text { لا يصل الحبيب إلى الحبيب }
\end{aligned}
$$

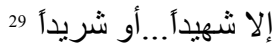

28 بالمبو، ميخائيل، كيف طرد الفلسطينيون. 24

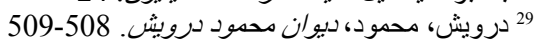


ويقرن الثـاعر في قصيدة "دمشق" حركة الفلسطيني وتفجّره في وجه العدو، بوصفها نتاجأ لاغتسال

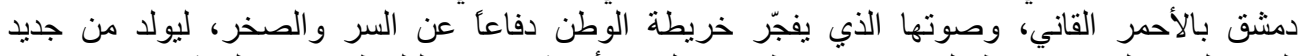
النهار/الزمن العربي بعد طو ال احتجاب و انطفاء. يقول بعد أن اشتد ساعد الفلسطيني بقوة الدمشقي:

$$
\begin{aligned}
& \text { أنا ساعة الصفر } \\
& \text { جئت أقول: } \\
& \text { أحاصر هم قاتلا أو قتيل }
\end{aligned}
$$

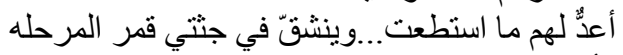

$$
\begin{aligned}
& \text { و أمتنق المقصله } \\
& \text { أحاصر هم ! قاتلا أو قتيل } \\
& \text { و أنسى الخلافة في السفر العربي الطويل } \\
& \text { إلى القمح و القدس و المستحيل فيل النيل } \\
& \text { يؤرخني خنجران } \\
& \text { العدو } \\
& \text { وعورة طفل صغير تسمّونه } \\
& \text { بردى } \\
& \text { وسميّته مبتدا } \\
& \text { و أخبرته أنني قاتل أو قتيل }
\end{aligned}
$$

تستند الأبيات إلى محورين لغويين: الأول توظيف الثاعر ضمير المتكلم "أنا"، و الثاني توظيف التناص

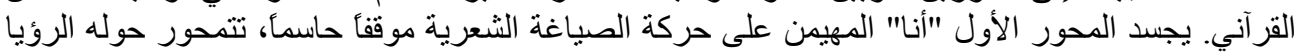

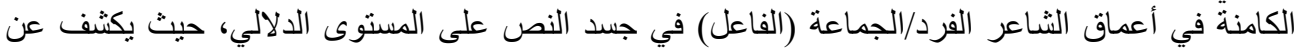

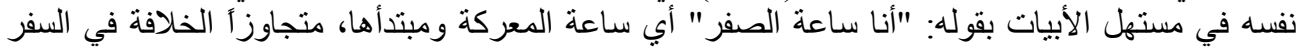

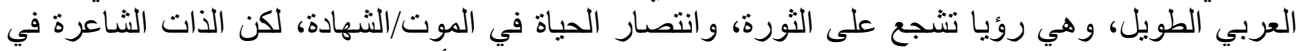

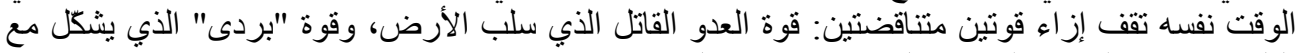

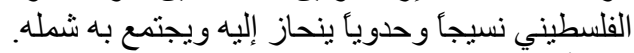

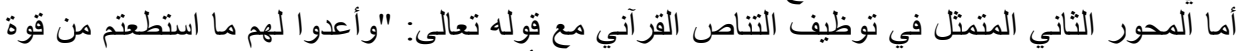

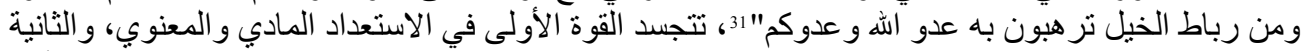

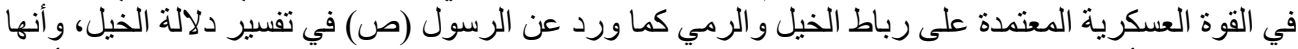

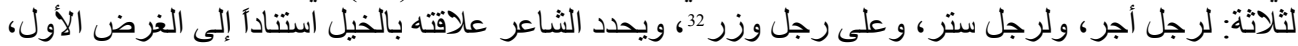

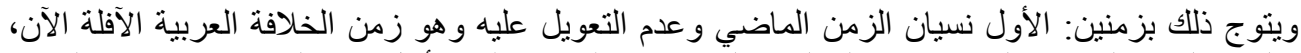

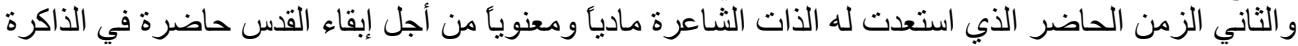

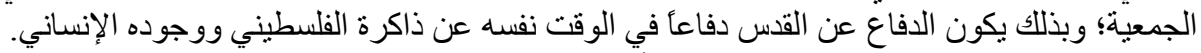

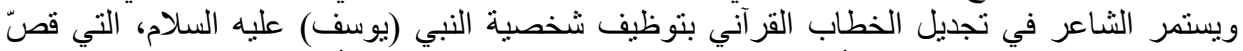

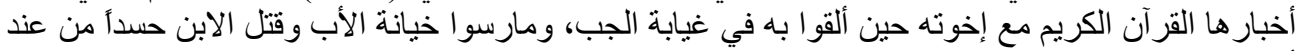

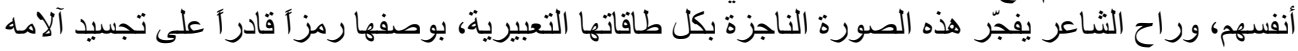

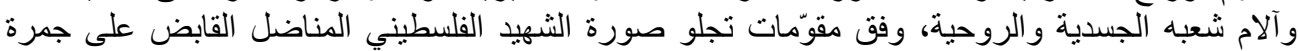


الحباة، ومصوّرأ في الوقت نفسه درامية الحباة، للالالة على المحنة التي يمر بها الفلسطيني في العصر

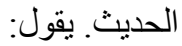

$$
\begin{aligned}
& \text { أرخيت ظلي و انتظرت، اخترت أصغر } \\
& \text { صخرة وسهرت. كسّرت الخر افة و انكسرت الترت } \\
& \text { ودرت حول البئر حتى طرت من من نفسي }
\end{aligned}
$$

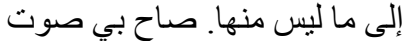

$$
\begin{aligned}
& \text { عميق: ليس هذا القبر قبرك، فاعني إنذرت }
\end{aligned}
$$

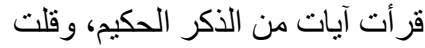

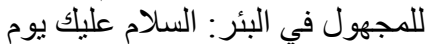

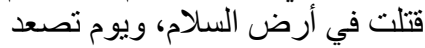

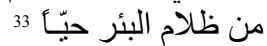

ترتكز الأبيات في إنتاج دلالاتها على محورين اثثين: يتمثل الأول في توظيف التناص القرآني، ويعتمد

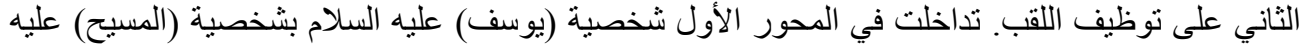

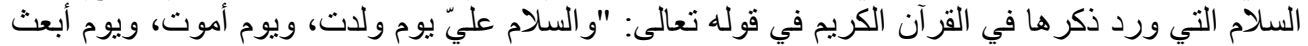

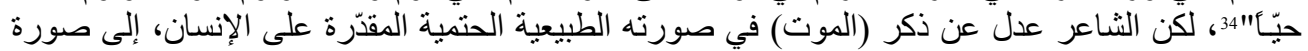

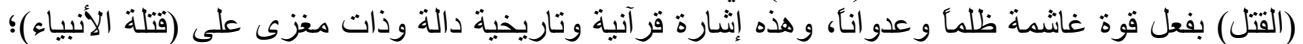

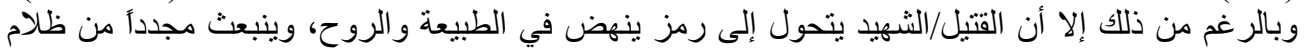

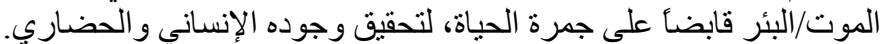

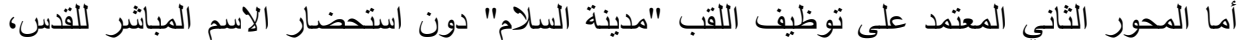

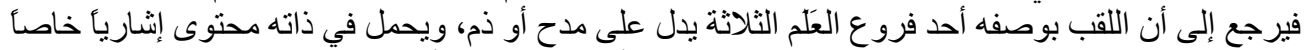

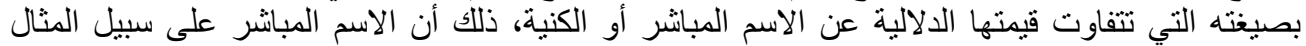

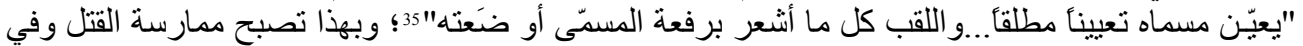

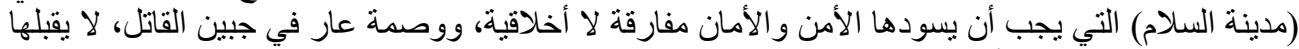

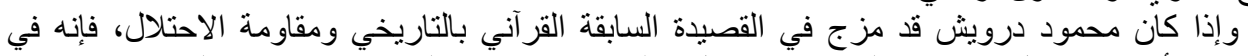

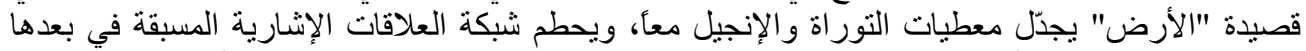

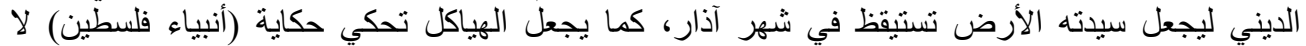

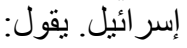

$$
\text { وفيدني شهر آذار تستيقظ الخيل }
$$

كأن الَياكل تستفسر الآن عن أنبياء فلسطين في بدئها

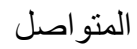

هذا اخضر ارل المدى واحمرار الحجارة

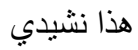

و هذا خروج المسيح من الجرح و الريح أخضر مثل البنات يغطي مساميره و وقيودي الجير 


$$
\text { و وذذا صنيدي الفتى العربي إلى الحلم و القس } 36
$$

يشير شهر آذار على المستوى الواقعي إلى قمع الاحتلال انتفاضة الأرض، التي قام بها سكان فلسطين الماني

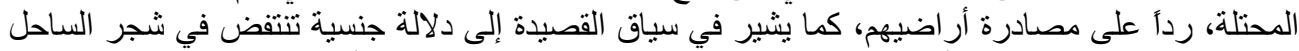

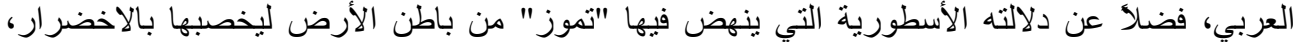

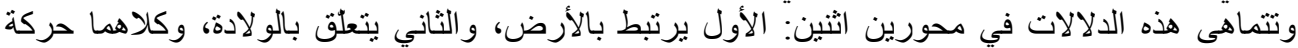

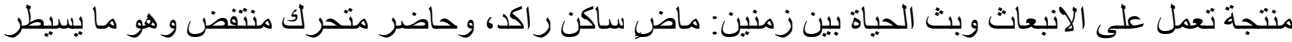

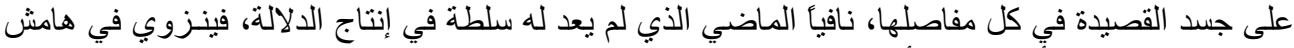

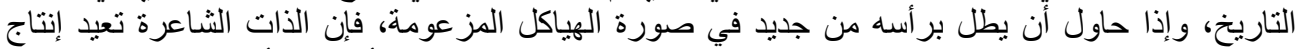

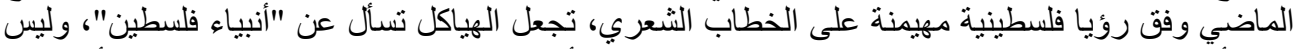

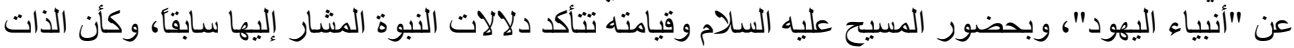

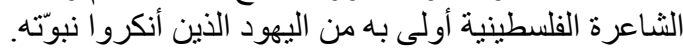

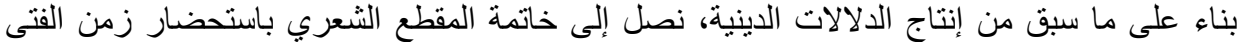

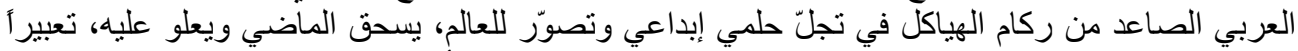

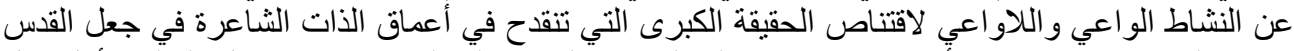

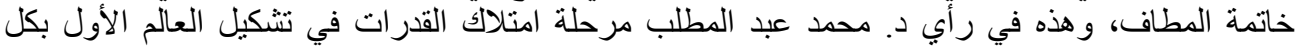

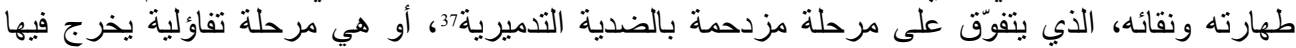

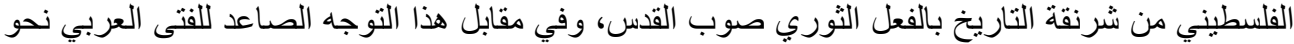

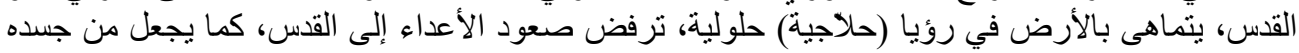
متر اسأ يمنعهم من المرور، وذللك في خاتمة القصيدة، حيث يقول:

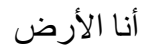

$$
\begin{aligned}
& \text { يا أيها الذاهبون إلى حبة القمح في مهدها }
\end{aligned}
$$

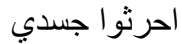

$$
\begin{aligned}
& \text { أيها الذا هبون إلى جبل النار }
\end{aligned}
$$

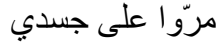

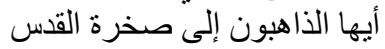

$$
\begin{aligned}
& \text { مرّو ا على جسدي الهي }
\end{aligned}
$$

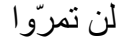

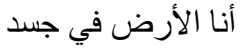

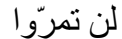

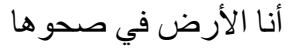

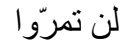

$$
\begin{aligned}
& \text { أنا الأرضرض، يا أيها العابرون على الأرض في صحوها }
\end{aligned}
$$

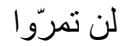

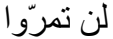

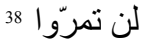




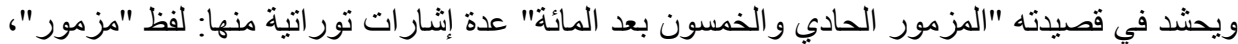

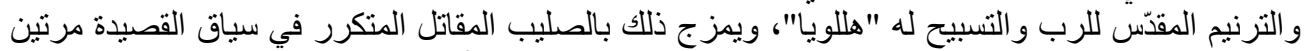

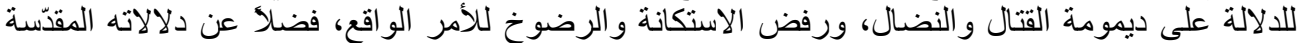

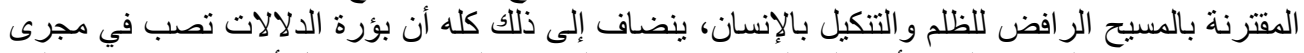

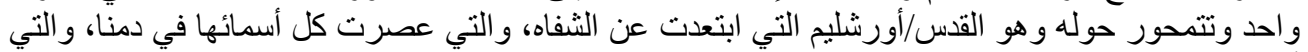

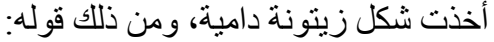

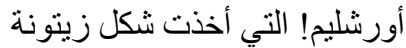

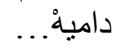

صار جلدي حذاء

للأساطير وُالأنبياء

بابلي أنت. طوبى لمن جاور الليلة الآتيهُ و أنا فيك أقرب

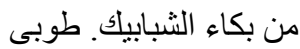
لإمام المغنين في الليلة الماضيه و إمام المغنين كان. وجسمي كائن و أنا فيك كوكب المغن كان

يسقط البعد في ليل بابل

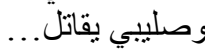

هللويا.

هللويا.... - ملايا.

هللويا....

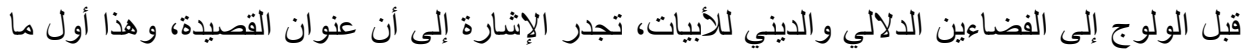

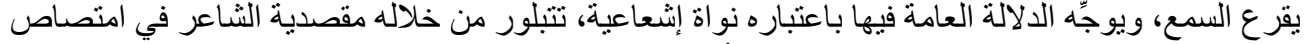

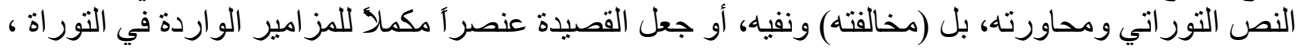

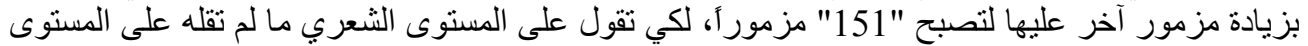

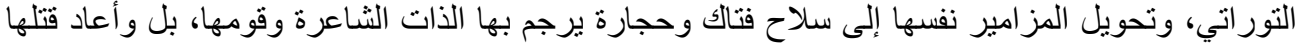

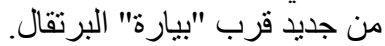

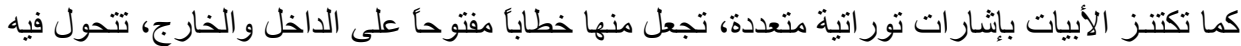

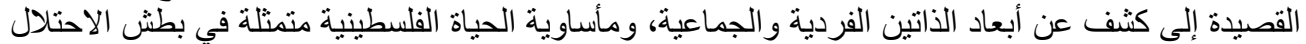

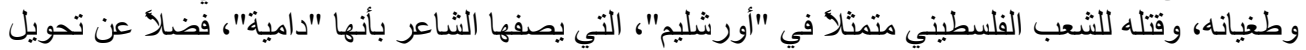

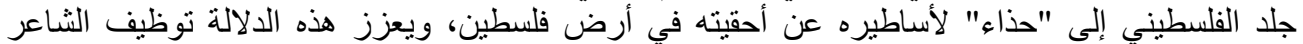

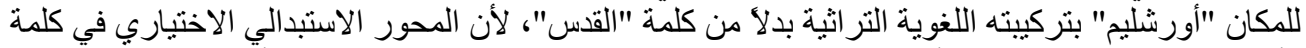

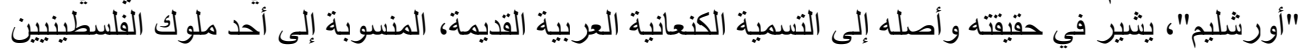

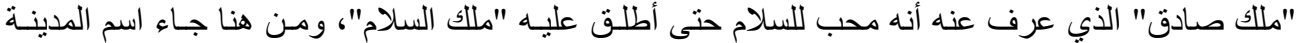

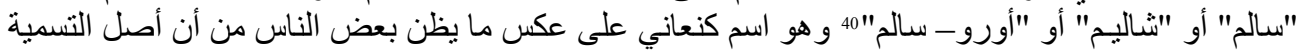

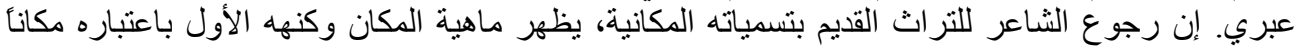

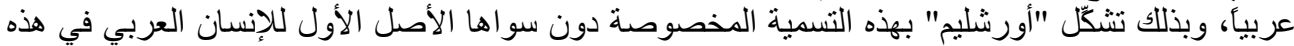

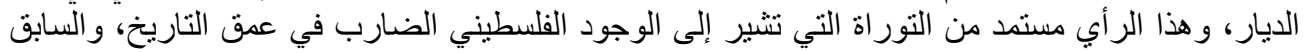


على الوجود اليهودي بمئات السنين، وذللك حين قدم "إبراهيم" عليه السلام إلى "الخليل"، ولم يجد مكاناً فيها

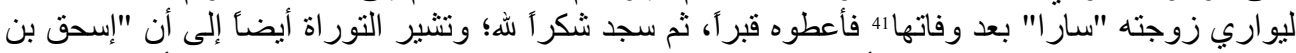

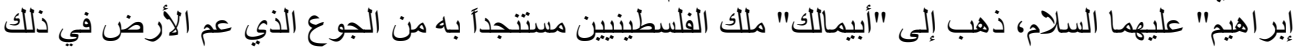

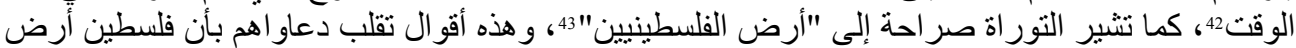
بلا شعب ر رأسأ على عقب.

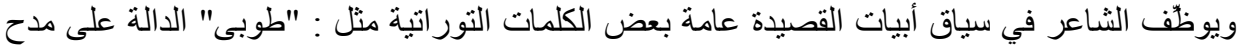

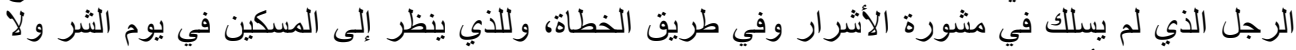

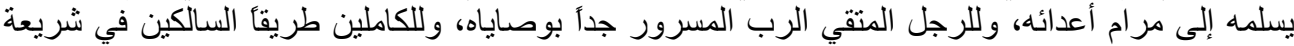

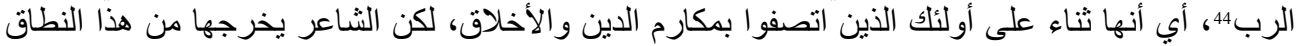

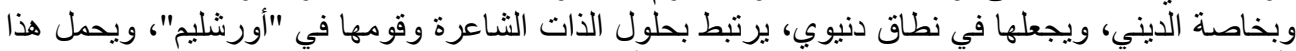

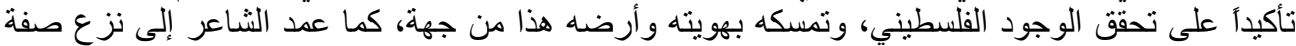
القداسة الدينية عن اللفظة "طوبى الوجى" من جهة أخرى.

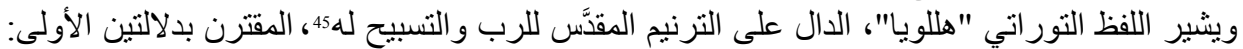

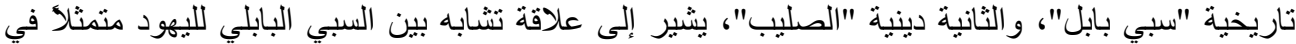

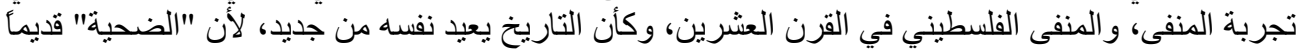

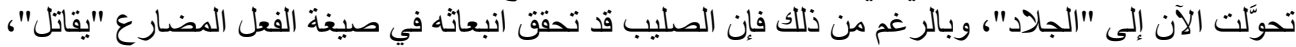

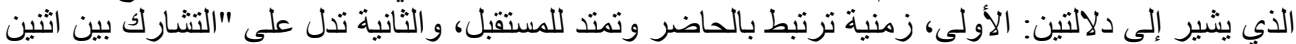

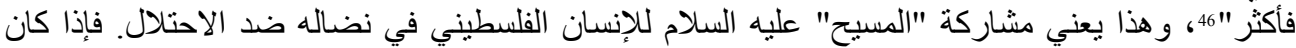

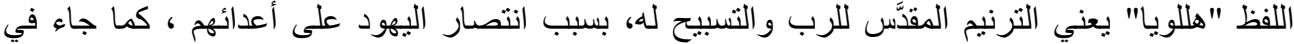

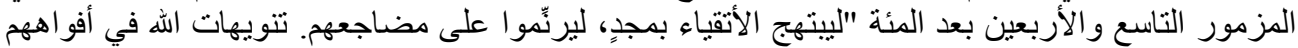

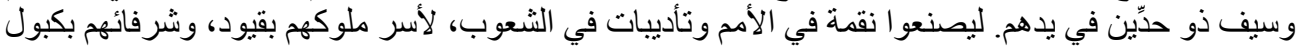

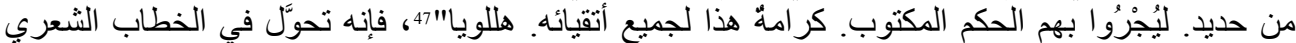

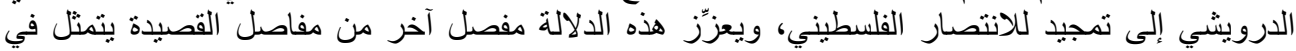

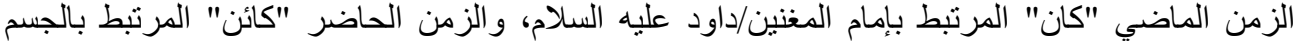
"جسمي كائن/ألفلسطيني المعاصر ، الذي يملك الحاضر ويفرض سيطرنه على الزمن الزئه الماضي.

\title{
الخاتمـة
}

كثف البحث عن رؤية الثاعر الفلسطيني محمود درويش في إعاداة نركيب نقوش الهوية المقدية

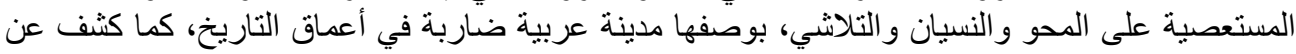

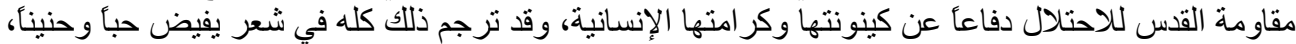

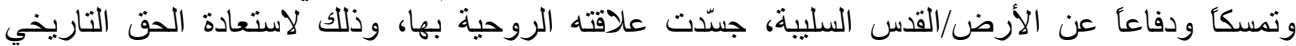

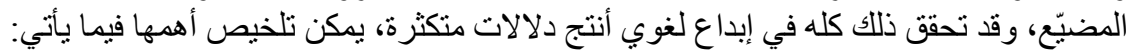

\author{
2324 انظر العهـ القديج، سفر التكوين، الإصحاح

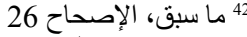

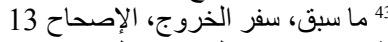

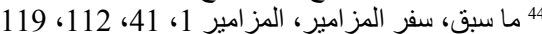

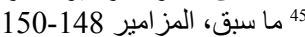

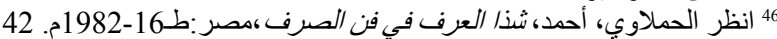 \\ 47/العهة القديم، سفر المزامير، ، المزمور 149
}


عبّر محمود درويش ـو غيره من شعر اء فلسطين- في مر احله الثعرية المتعددة عن الهوية الفلسطينية، وتمايزها عن هوية الآخر اليهودي؛ بسبب دأب الاحتلال على تمزيقها وطمس ملامحها، وبخاصنة فئس في مدينة

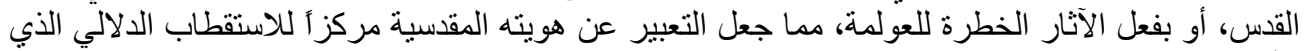

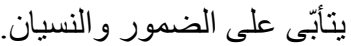
عاد الثاعر إلى التاريخ اليهودي موظفاً من خلاله شخصيات أنبياء أوكهنة بني إسر ائيل مثل (إثبعيا)، و

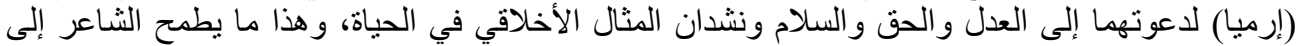

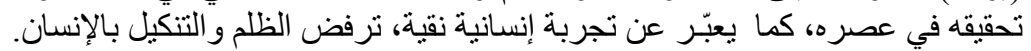

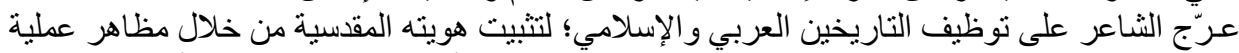

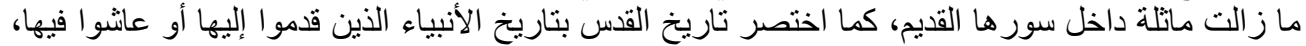

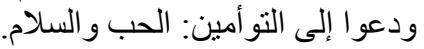

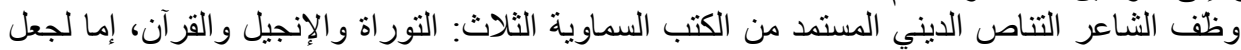

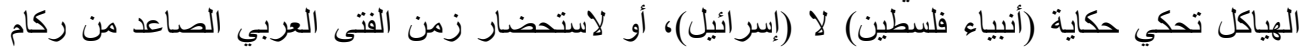

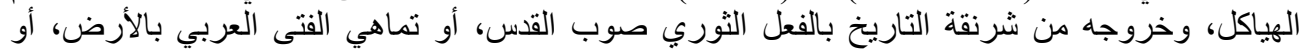

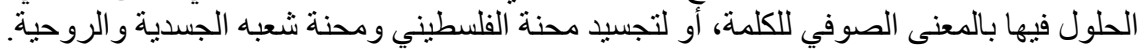

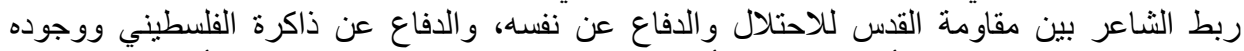

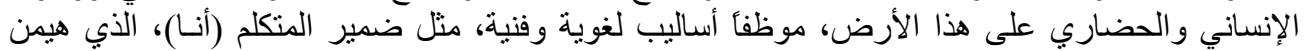

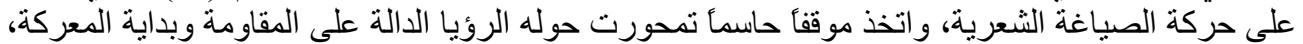

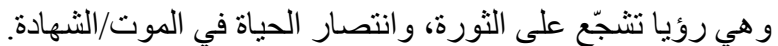

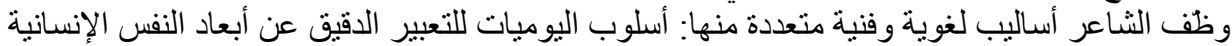

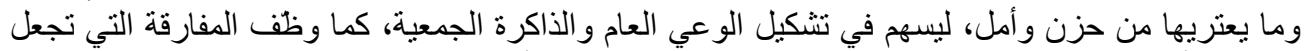

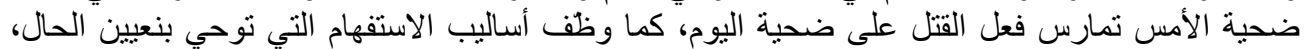
وكأن الثاعر يعجب أو ينكر على الرواة الذين يختلفون على عروبة المكان/القدس. 